\section{DIGITAL COMMONS \\ @ UNIVERSITY OF SOUTH FLORIDA}

\section{ABO: Interactive Journal for Women in the Arts, 1640-1830}

Volume 11

Issue 1 Summer 2021

Article 13

2021

\title{
The Future of the Field: Notes from Lockdown
}

Sofia Prado Huggins

TCU, s.c.huggins@tcu.edu

Susannah B. Sanford

TCU

Follow this and additional works at: https://digitalcommons.usf.edu/abo

Part of the Dramatic Literature, Criticism and Theory Commons, Educational Methods Commons, Feminist, Gender, and Sexuality Studies Commons, Literature in English, British Isles Commons, and the Nonfiction Commons

\section{Recommended Citation}

Prado Huggins, Sofia and Sanford, Susannah B. (2021) "The Future of the Field: Notes from Lockdown," ABO: Interactive Journal for Women in the Arts, 1640-1830: Vol.11: Iss.1, Article 13.

http://doi.org/10.5038/2157-7129.11.1.1264

Available at: https://digitalcommons.usf.edu/abo/vol11/iss1/13

This Conversation is brought to you for free and open access by Digital Commons @ University of South Florida. It has been accepted for inclusion in ABO: Interactive Journal for Women in the Arts, 1640-1830 by an authorized administrator of Digital Commons @ University of South Florida. For more information, please contact digitalcommons@usf.edu. 


\section{The Future of the Field: Notes from Lockdown \\ Creative Commons License \\ (c) (1) \& 8}

This work is licensed under a Creative Commons Attribution-Noncommercial 4.0 License

\section{Cover Page Footnote}

We would like to thank the Editorial Board of $A B O$ for space for reflection on the changing landscape of academia. 


\section{The Future of the Field: Notes from Lockdown ${ }^{1}$}

The kids are (tentatively) in bed, though they will soon ask for water or another hug or one more story, and this is our time to take care of ourselves. We, two modern-day eighteenth-centuryists, ${ }^{2}$ virtually toast each other's futures over Skype. We can see those futures so clearly:

Imagine, if you will, a castle. Perhaps a Gothic one. You know, the type with dark corners and pokey spires and unwelcoming front doors. Something is definitely lurking at the end of a dark hallway. Things are looking. . . well, rather grim.

Everything looks grim in These End Times. We've spent the day "taking care" in so many ways: teaching (our students and our children, who are suddenly also our students), answering frantic emails, preparing food, and possibly trying to work on our dissertations that loom menacingly over our heads. We must care for our own intellectual pursuits too-or so we are told.

In addition to the dissertation, we have approximately 500 other projects we are working on so we can add lines to our CVs. How many articles can we submit for publication? How many weird online networking events does it take? How many meetings and emails and Zoom conferences do we need to go to before someone, ${ }^{3}$ anyone recognizes our names enough to pluck our job application out of the pile of hundreds of other equally qualified, equally desperate, equally exhausted candidates?

Besides the academic things contributing to our overwhelming sense of doom, half a million people have left the earth in the last year. There was an election in there somewhere, and a subsequent attempt at a coup d'état. ${ }^{4}$ We're shouldering the mental load of home care, homeschooling, meal planning, the endless anxiety baking. ${ }^{5}$ Somehow, we explain to our kids that they can't go to school. That they can't see their friends or grandparents. (We can't see our friends either. We do not

\footnotetext{
${ }^{1}$ In this essay, we employ footnotes as a method for comic relief. We have found that snarky asides are our only healthy coping mechanism besides therapy. These footnotes signify the symbiotic relationship between form and function.

${ }^{2}$ The long eighteenth century runs from approximately 1640 to the present.

${ }^{3}$ Zoom uses up way too many spoons. (Spoon Theory: https://butyoudontlooksick.com/articles/written-by-christine/the-spoon-theory/)

${ }^{4}$ We baked a lot of bread during these political crises. We do not take responsibility for any flour shortages and will not be taking questions at this time.

${ }^{5}$ It takes approximately two loaves of sourdough to write 250 words or send a tweet.
} 
feel good about this.) Which means they are with us. All the time. There's no such thing as a room of one's own.

Even at the ends of our ropes, we feel like we must keep working. Maybe we've taken the publish or perish thing a bit too literally, but perishing seems like an actual distinct possibility between the global pandemic and the climate disasters and political turmoil. We strategize frantically, trying to make the gloom more...pleasant? survivable? Is it better to get up at 5AM to try and write, or should we spend our precious evening hours pretending we have the brain power to form coherent sentences? How many lists can we make before feeling productive? What if we bargain and only write 100 words today? Is that enough?

Spoiler alert: it is not enough.

We were told if we worked hard and followed the rules, we could achieve success. That's the American Dream, right? And we have worked so hard. We are overachievers, after all. ${ }^{6}$ When we started our doctoral program five or six years ago, in the naivete of the Before Times, we knew it would be incredibly difficult to get a tenure-track position. We came in with our eyes wide open looking up at the mountain we had to climb. We were so focused on the uphill battle we didn't notice the trap door opening up under our feet. ${ }^{7}$

There are virtually no jobs for us to apply to anymore. The handful of positions in our field receive hundreds of applicants. Getting a full-time academic position is as likely as winning the lottery. Even publishing the article we've been meticulously revising feels painful and draining. And we need the article (and several more) to get the Zoom interview, the interview to get the campus visit, and the campus visit to get the job.

There aren't any safety nets in academia. ${ }^{8}$ Burnout is real and, frankly, at this point we suspect our burnout is somehow the purpose of academia. Like this entire thing is designed precisely to extract all our labor until we are but withered husks. Graduate students in the humanities generally live on stipends that are below the poverty line. We are told to think of graduate school as a sort of apprenticeship but in order to move up in the academic hierarchy we are expected to produce at the rate of established scholars. Do we stick it out long enough to get enough publications out to finally matter or do we find jobs with health care

${ }^{6}$ Enneagram types one and three, reporting for duty.

${ }^{7}$ We have had considerably fewer questionable exploits than Don Giovanni at this point because where would we even find the time?

${ }^{8}$ And we are the lucky ones, with partners who can share the economic burden. 
that let us afford our medications? So far, the end of the graduate school road looks like a gaping chasm with a bridge that was never finished, and we are careening toward it, unable to figure out how to jump across. What, in actuality, are we getting out of this?

If we have to listen to another panel of tenured professors bemoan the "future of the field" to an audience of graduate students who can practically feel their own futures being sucked out of them with vampiric determination, we will scream. At this point, we do not have the energy for painstakingly niche discussions of what interdisciplinary methodology or hermeneutic will "save the humanities." 9

We ARE the future of the field. Save US.

${ }^{9}$ Our executive function spoons are teaspoons now. 